\title{
Relationship among Periodontal Disease, Apical Periodontitis and Offspring Health
}

Relação entre Doença Periodontal, Periodontite Apical e Saúde da Prole

Relación entre Enfermedad Periodontal, Periodontitis Apical y Salud de la Descendencia

Maria Sara de Lima Coutinho MATTERA

Multicenter Post-Graduate Program in Physiological Sciences, SBFis, Department of Basic Sciences, São Paulo State University (Unesp), School of Dentistry, Araçatuba, Brazil https://orcid.org/0000-0003-2288-708X

Thaís Verônica Saori TSOSURA

Multicenter Post-Graduate Program in Physiological Sciences, SBFis, Department of Basic Sciences, São Paulo State University (Unesp), School of Dentistry, Araçatuba, Brazil https://orcid.org/0000-0003-1708-4071

Renato Felipe PEREIRA

Multicenter Post-Graduate Program in Physiological Sciences, SBFis, Department of Basic Sciences, São Paulo State University (Unesp), School of Dentistry, Araçatuba, Brazil https://orcid.org/0000-0002-4696-4070

Fernando Yamamoto CHIBA

Department of Preventive and Restorative Dentistry, São Paulo State University (UNESP), School of Dentistry, Araçatuba - SP, Brazil https://orcid.org/0000-0003-4406-405X

Fernando MARANI

Multicenter Post-Graduate Program in Physiological Sciences, SBFis, Department of Basic Sciences, São Paulo State University (Unesp), School of Dentistry, Araçatuba, Brazil https://orcid.org/0000-0003-3169-612X

Bianca Elvira BELARDI

Multicenter Post-Graduate Program in Physiological Sciences, SBFis, Department of Basic Sciences, São Paulo State University (Unesp), School of Dentistry, Araçatuba, Brazil https://orcid.org/0000-0002-5564-8256 Gestter Willian Lattari TESSARIN University Center North Paulista (UNORP), São José do Rio Preto, SP, Brazil https://orcid.org/0000-0002-7355-9652

Rodrigo Martins dos SANTOS

Multicenter Post-Graduate Program in Physiological Sciences, SBFis, Department of Basic Sciences, São Paulo State University (Unesp), School of Dentistry, Araçatuba, Brazil https://orcid.org/0000-0002-5122-275X

Doris Hissako MATSUSHITA Multicenter Post-Graduate Program in Physiological Sciences, SBFis, Department of Basic Sciences, São Paulo State University (Unesp), School of Dentistry, Araçatuba, Brazil https://orcid.org/0000-0003-3753-229X

\section{Abstract}

The relationship between maternal health and the fetal environment has been widely discussed in recent decades. Several studies have shown that insults that occur during the perinatal period modify fetal development, leading to harmful long-term results that culminate in pathologies in adulthood. Periodontal diseases (PD) comprise a wide range of inflammatory conditions that affect the supporting structures of the teeth (the gingiva, bone and periodontal ligament). Apical periodontitis (AP) is an inflammation at the apex of the thoot root usually caused by infection by bacteria from the root canal system. The present study aims to show the effects of maternal oral inflammations on the offspring health. The study provides information that both, maternal PD and AP, have negative effects in the short and long-term on the offspring health. Thus, adequate oral health can prevent adverse pregnancy outcomes and permanent changes in adult offspring. That is, oral hygiene during pregnancy should be encouraged.

Descriptors: Fetal Development; Low Birth Weight; Periapical Periodontitis; Periodontal Diseases.

\section{Resumo}

A relação entre a saúde materna e o ambiente fetal tem sido amplamente discutida nas últimas décadas. Vários estudos têm mostrado que os insultos que ocorrem durante o período perinatal modificam o desenvolvimento fetal, levando a resultados prejudiciais a longo prazo que culminam em patologias na vida adulta. As doenças periodontais (DP) compreendem uma ampla gama de condições inflamatórias que afetam as estruturas de suporte dos dentes (gengiva, osso e ligamento periodontal). A Periodontite Periapical (PA) é uma inflamação no ápice da raiz do pé, geralmente causada por infecção por bactérias do sistema de canal radicular. $O$ presente estudo tem como objetivo mostrar os efeitos das inflamações orais maternas na saúde da prole. O estudo fornece informações de que tanto a DP materna quanto a PA têm efeitos negativos a curto e longo prazo na saúde da prole. Assim, uma saúde bucal adequada pode prevenir resultados adversos da gravidez e mudanças permanentes na prole adulta. Ou seja, a higiene oral durante a gravidez deve ser incentivada.

Descritores: Desenvolvimento Fetal; Baixo Peso ao Nascer; Periodontite Periapical; Doenças Periodontais.

\section{Resumen}

La relación entre la salud materna y el entorno fetal se ha debatido ampliamente en las últimas décadas. Varios estudios han demostrado que las agresiones que se producen durante el período perinatal modifican el desarrollo fetal, dando lugar a resultados nocivos a largo plazo que culminan en patologías en la edad adulta. Las enfermedades periodontales (EP) comprenden una amplia gama de afecciones inflamatorias que afectan las estructuras de soporte de los dientes (encías, huesos y ligamento periodontal). La periodontitis periapical (PA) es una inflamación en el vértice de la raíz del pie, generalmente causada por una infección por bacterias en el sistema de conductos radiculares. El presente estudio tiene como objetivo mostrar los efectos de las inflamaciones orales maternas sobre la salud de la descendencia. El estudio aporta información de que tanto la EP como la PA materna tienen efectos negativos a corto y largo plazo sobre la salud de la descendencia. Por lo tanto, una salud bucal adecuada puede prevenir resultados adversos del embarazo y cambios permanentes en la descendencia adulta. Es decir, se debe fomentar la higiene bucal durante el embarazo.

Descriptores: Desarrollo Fetal; Bajo Peso al Nacer; Periodontitis Periapical; Enfermedades Periodontales.

\section{INTRODUCTION}

The relationship between maternal health and the fetal environment has been widely discussed in recent decades. Several studies have shown that insults that occur during the perinatal period modify fetal development, leading to harmful long-term results that culminate in pathologies after complete 
development ${ }^{1,2}$. This hypothesis is called fetal programming $^{2}$, prenatal programming or fetal origin of adult disease ${ }^{3}$.

One of the first epidemiological findings on fetal programming emerged from the historical cohort study of Dutch famine (1944-45) in Amsterdam, which occurred Second World War ${ }^{4}$. In this research, it was found that offspring of women exposed to food shortages during the beginning of the gestational period (caused by the decrease in caloric supply) had a higher incidence of obesity at nineteen years of age. In addition, subsequent studies have reported that adult offspring of pregnant women who were exposed to famine showed decreased glucose tolerance and hyperinsulinemia compared to those who were not exposed to Dutch famine during gestation ${ }^{5}$. Such observations reveal that the importance of the perinatal period, the period in which organogenesis and tissue differentiation occurs, is a gap for susceptibility to adverse environments ${ }^{1}$.

Fetal programming has been proposed as the mechanism responsible for low birth weight (LBW), child growth and subsequent illness ${ }^{6}$. This mechanism was inserted by a researcher named David Barker, responsible for investigating the relationship between LBW and coronary heart disease in adults ${ }^{7}$.

LBW can be the result of preterm birth (PTB) and/or intrauterine growth restriction (IUGR) (birth with weight below the limit value for gestational age, usually being born at term) ${ }^{8}$. Studies have found that oral inflammation, particularly periodontal disease (PD) and apical periodontitis (AP), are correlated with gestational outcomes $^{8-13}$. These inflammations are sources of bacteria and inflammatory mediators that can reach the bloodstream and consequently the fetoplacental unit ${ }^{14}$. In this context, this manuscript discusses the pathogenic processes associated with maternal oral inflammation, gestational outcomes and the general health of the offspring.

\section{PREGNANCY AND ORAL HEALTH CONDITIONS}

Pregnancy is a period when a woman goes through a series of physiological changes that affect the body, as well as the cavity of mouth $^{15}$. During pregnancy, women become more susceptible to oral health conditions, such as tooth decay, gingivitis and $\mathrm{PD}^{16}$ due to changes in the diet (introduction of more carbohydrates and / or higher food frequency), hyperacidity of the oral environment due to vomiting, hormonal changes, which associated with inattention in maintaining oral hygiene, favor the installation of oral diseases ${ }^{17-20}$. In decorrence, pregnant women are considered patient of temporary dental risk. However, there is a certain resistance on the part of pregnant women to dental treatment, as they believe that the intervention will bring risks to the baby's development and life ${ }^{21}$.

From the 13th week of pregnancy, it is the best and safest period for dental treatment. Even so, fear and unpreparedness are the main reasons that lead dentists to refuse to provide dental care to pregnant women. The postponement of dental care to the late puerperium, instead of solving the problem as soon as it is diagnosed, can cause greater damage due to the development of oral diseases ${ }^{16}$.

PERIODONTAL DISEASE AND APICAL PERIODONTITIS

The PD is a common oral disease among pregnant women ${ }^{22,23}$. Gingivitis is an inflammation in the supporting tissue of teeth $^{11,24,25}$ and affects more than half pregnant women $^{26}$. The increase in plasmatic progesterone concentration increases the permeability of gingival blood vessels, making the area more sensitive to local irritants, such as dental plaque ${ }^{27}$. In addition, estrogen decreases gingival keratinization and increases glycogen in periodontal tissues, compromising the effectiveness of the epithelial barrier ${ }^{28}$. Gingivitis is usually reversible ${ }^{27}$. However, when untreated, it progresses to periodontitis, in which the inflammation extends to the supporting tissues ${ }^{11,25}$, resulting in tooth loss ${ }^{25}$. Periodontitis affects a smaller proportion in pregnant women, approximately $30 \%$.

PD is an infection caused by anaerobic Gram-negative bacteria. As the disease progresses, these complexes are modified. Initially, colonization of the periodontal sulcus in the early stages of dental plaque formation, the complexes are "blue", "green", "yellow" and "purple". As the PD progresses, due to the maturation of the biofilm, the complex is modified with the appearance of the "orange" cluster (Campylobacter rectus, F.nucleatum, Peptostreptococcus micros, Prevotella intermedia and Prevotella nigrescens) and of more aggressive bactéria of the "red" "(Porphyromonas gingivalis, Tannerella forsythia and Treponema-denticola) ${ }^{29,30}$.

In addition to PD, dental caries is another prevalent oral disease in pregnant women ${ }^{31}$. This pathology is characterized by the demineralization of dental structures, such as enamel, dentin and cementum ${ }^{32}$ caused by organic acids produced by bacteria present on the surface of teeth in the form of dental 
plaque $^{22}$. The progression of this disease develops a cavity in the crown or on the root surface in pulp-exposed and development of $\mathrm{AP}^{33}$, an inflammation at the apex of the thoot root usually caused by infection by bacteria from the root canal system ${ }^{34-37}$. These infected channels become a persistent source of bacterial pathogens that secondarily stimulate the inflammatory response in the region surrounding the apex of the thoot root called the periapical region ${ }^{36}$.

PATHOGENIC MECHANISMS AND PREGNANCY

Although there are differences between $P D$ and $A P$ in terms of etiology and pathology, both are oral infections predominantly by anaerobic Gram-negative ${ }^{38}$. The membrane of gram-negative microorganisms has endotoxins called lipopolysaccharides (LPS) ${ }^{39,40}$, which can be recognized by Toll-like receptors (TLRs), especially Toll-like receptor 4 (TLR4), present in cells of the innate immune system ${ }^{41,42}$, responsible for activating an inflammation, through a signaling pathway, to exterminate the biological agents ${ }^{43}$. Inflammation caused by bacteria has an important role in pathogens associated with adverse pregnancy outcomes, such as PTB and fetal injury ${ }^{43}$.

Pathogenic mechanisms involved in the association between mouth infections and pregnancy outcomes include the spread of periodontal pathogens, endotoxins and/or inflammatory mediators from the oral cavity to the fetal-placental unit via hematogenous ${ }^{44}$.

In a serological analysis, Cappelli et al. $(2009)^{45}$ found that Porphyromonas gingivalis ( $P$. gingivalis) is the most abundant bacterium in pregnant female baboons with ligature-induced periodontitis. Ercan et al. ${ }^{10}$ periodontal pathogens were found, such as Tannerella forsythia, Campylobacter rectus (C. rectus), $P$. gingivalis and Fusobacterium nucleatum ( $F$. nucleatum), both in subgingival plaque and amniotic fluid samples of women with generalized periodontitis. This co-occurrence may explain the source of these bacteria. In addition, Blanc et al. ${ }^{46}$ detected a significantly higher number of bacteria (Eikenella corrodens and $F$. nucleatum) in the placentas of mothers with PD than in the placentas of mothers without PD.

Inside the uterus, periodontopathogens can induce an inflammatory response ${ }^{47}$ and cause adverse pregnancy outcomes. Katz et al. (2009) 48 found that $P$. gingivalis can colonize placental tissue, as antigens of this bacterium were detected in trophoblasts (outermost layer of the blastocyst), deciduous cells (are endometrial cells that have undergone modification for implantation of the blastocyst) and amniotic epithelial cells of women who had PTB complicated by chorioamnionitis. In addition, infection by $P$. gingivalis, in different periods of pregnancy, promoted (in the serum and placenta) an increase in the concentrations of inflammatory cytokines, such as Interleukin- 6 (IL-6) and the tumor necrosis factor alpha ( TNF$\alpha)$ and therefore LBW in rats. In addition, it proved that the period of greatest risk for diffusion of the process was before or in the middle of pregnancy ${ }^{49}$.

Ao et al. ${ }^{50}$ demonstrated that the infection of the dental pulp by $P$. gingivalis in pregnant female mice caused changes in the placental tissues, verified by the degeneration of the amnion with partial detachment of the surface of the chorionic plate and trophoblast necrosis. In this same study, there was an increase in the number of polymorphonuclear leukocytes and macrophages in placental tissues, associated with the increase in the localized expression of cyclooxygenase-2 (COX2) and proinflammatory cytokines, as TNF- $\alpha$. COX-2 is an enzyme responsible for the synthesis of prostaglandins (PGs) 50 which are stimulators of myometrium contractility ${ }^{51,52}$.

Physiologically, intra-amniotic levels of $P G$ and pro-inflammatory cytokines, such as TNF- $\alpha$ and IL-1 $\beta$, increase progressively during pregnancy until high levels of these substances induce labor ${ }^{29,53}$. Pro-inflammatory cytokines stimulate synthesis of $P G$ by uterine tissues ${ }^{54}$. Knowing this, changes that occur during this process, such as infections, can shorten labor ${ }^{29}$.

Offenbacher et al. $^{53}$ demonstrated a significant increase in intra-amniotic levels of prostaglandin E2 (PGE2) and TNF- $\alpha$ in pregnant rats with periodontitis compared to pregnant rats without this disease. Other studies have found an increase in the concentrations of PGE2, IL-6 and IL-1 $\beta$ in the gingival crevicular fluid of women who had a PTB ${ }^{38,55}$. Collins et al. ${ }^{56}$ indicated a statistically significant association between increased of PGE2 and TNF- $\alpha$ levels and fetal growth retardation.

Yeo et al. ${ }^{57}$, to investigate the consequences of infection by $C$. rectus, performed an experimental model using the subcutaneous, intra-chamber challenge with live $C$. rectus in pregnant female mice. These authors verified that the infected animals had fetuses with IUGR. Similar results were found after subcutaneous infection with $P$. gingivalis ${ }^{58}$. Bobetsis et al. ${ }^{59}$ demonstrated that $C$. rectus infection in rats promotes hypermethylation in the gene promoter of insulin-like growth factor 2 , 
causing attenuation of this gene involved in fetal growth and development, contributing to IUGR.

In 1996, Offenbacher et al. ${ }^{60}$ conducted a pioneering study to assess the influence of poor oral hygiene on PTB and the occurrence of LBW. The results of this study showed that pregnant women with $\mathrm{PD}$ were 7.5 times more at risk of having PTB with LBW than pregnant women with good periodontal health. Subsequently, several other studies have indicated an association between maternal PD and pregnancy complications ${ }^{18,61-64}$. Previous studies from our laboratory have shown that offspring of rats with PD had LBW compared to offspring of control rats ${ }^{65,66}$.

Interventionist study by López et al. ${ }^{67}$ demonstrated that pregnant women who underwent gingivitis treatment before the 28th week of pregnancy had a lower incidence of lowbirth-weight preterm births (LBWPB) than pregnant women who remained exposed to gingivitis throughout the gestational period. López, Smith and Gutierrez ${ }^{67}$ also found that periodontal treatment among pregnant women with periodontitis reduced the incidence of LBWPT.

Another demonstrated evidence that $C$. rectus is capable of modifying or placental labyrinth (site that promotes exchange of nutrients between fetus and mother ${ }^{68}$. This change can cause a reduction in fetal nutrition and blood flow during pregnancy, compromising the individual's size and weight ${ }^{29}$. In addition, subcutaneous infections located by $P$. gingivalis in hamsters can reduce fetal weight by up to $25 \%{ }^{56}$.

Because of this, the fetus undergoes adaptations prioritizing the expenditure of energy for tissues, such as the brain and heart. These adaptations decrease the development of other tissues, such as skeletal muscle, this is known as the thrifty phenotype hypothesis, leading these individuals to diseases as diabetes $^{69}$.

Although there are several studies that relate $\mathrm{PD}$ to adverse pregnancy outcomes, little research correlates the effects of AP maternal on the health of offspring. Leal et al. ${ }^{12}$ including 33 mothers of LBWPB (case group) and 30 mothers of newborns at term (control group), it was observed that chronic apical periodontitis was present in $54.5 \%$ of mothers in the case group and $20 \%$ in the control group. Additionally, mothers who had at least one dental periapical infections had significantly shorter duration of pregnancy and delivery to children with lower mean body weight than mothers who had no dental periapical infections ${ }^{13}$.
Mattera et al. ${ }^{66}$ observed that maternal PD in rats, induced by ligature, promotes LBW, insulin resistance, increased plasma cytokine concentrations, reduced content (translocation index to the plasma membrane) and RNA expression GLUT4 in the gastrocnemius muscle of adult offspring. In addition, maternal periodontal disease was able to activate inflammatory pathways in adult offspring, this activation was proven by increased expression of TNF- $\alpha$, NF-kBp65, NF-kBp50, ERK1 / 2 and $I K K \alpha / \beta^{65}$. However, there was no change in the DNA methylation of the GLUT4 gene and in the expression of JNK in adult offspring ${ }^{65}$.

A pioneering study in rats showed that maternal PA is capable of promoting changes in adult offspring, they are: 1 ) insulin resistance; 2) impaired the initial steps of insulin signalling (AKT and IRS1); 3) activate inflammatory pathways (IKKa / $\beta$ phosphorylation) in muscle tissue. However, there was no change in JNK phosphorylation, this fact is explained by this protein is important to counteract the changes found previously ${ }^{70}$.

FINAL CONSIDERATION

Adequate health can prevent adverse pregnancy outcomes and permanent changes in adult offspring. The oral hygiene during the pregnancy should be encouraged.

\section{REFERENCES}

1. Padmanabhan V, Cardoso RC, Puttabyatappa M. Developmental Programming, a Pathway to Disease. Endocrinology 2016;4:1328-40.

2. Godfrey KM, Barker DJ. Fetal programming and adult health. Public Health Nutr 2001;2B:61124.

3. Calkins K, Devaskar SU. Fetal origins of adult disease. Curr Probl Pediatr Adolesc Health Care 2011;6:158-76.

4. Ravelli GP, Stein ZA, Susser MW. Obesity in young men after famine exposure in utero and early infancy. N Engl J Med 1976;7:349-53.

5. Ravelli AC, van der Meulen JH, Michels RP, Osmond C, Barker DJ, Hales CN, et al. Glucose tolerance in adults after prenatal exposure to famine. Lancet 1998; 9097:173-7.

6. Drake AJ, Walker BR. The intergenerational effects of fetal programming: non-genomic mechanisms for the inheritance of low birth weight and cardiovascular risk. J Endocrinol 2004; 1:1-16.

7. Hales CN, Barker DJ. Type 2 (non-insulindependent) diabetes mellitus: the thrifty phenotype hypothesis. Int $\mathrm{J}$ Epidemiol 2013;5:1215-22.

8. Yeo BK, Lim LP, Paquette DW, Williams RC. Periodontal disease -- the emergence of a risk for systemic conditions: pre-term low birth weight. Ann Acad Med Singapore.2005;1:111-16. 
9. Arteaga-Guerra JJ, Cerón-Souza V, Mafla AC. Dynamic among periodontal disease, stress, and adverse pregnancy outcomes. Rev Salud Publica 2010;2:276-86.

10. Ercan E, Eratalay K, Deren O, Gur D, Ozyuncu $\mathrm{O}$, Altun $\mathrm{B}$, et al. Evaluation of periodontal pathogens in amniotic fluid and the role of periodontal disease in pre-term birth and low birth weight. Acta Odontol Scand 2013;3-4:5539.

11. Louro PM, Fiori HH, Louro Filho P, Steibel J, Fiori RM. Periodontal disease in pregnancy and low birth weight. J Pediatr 2001;1:23-8.

12. Leal AS, de Oliveira AE, Brito LM, Lopes FF, Rodrigues VP, Lima KF, et al. Association between chronic apical periodontitis and lowbirth-weight preterm births. $\mathrm{J}$ Endod 2015;3:353-7.

13. Harjunmaa U, Järnstedt J, Alho L, Dewey KG, Cheung YB, Deitchler $M$, et al. Association between maternal dental periapical infections and pregnancy outcomes: results from a crosssectional study in Malawi. Trop Med Int Health 2015;11:1549-58.

14. Ren H, Du M. Role of Maternal Periodontitis in Preterm Birth. Front Immunol 2017;8:139.

15. Vt H, T M, T S, Nisha V A, A A. Dental considerations in pregnancy-a critical review on the oral care. J Clin Diagn Res 2013;5:948-53.

16. Kandan PM, Menaga V, Kumar RR. Oral health in pregnancy (guidelines to gynaecologists, general physicians \& oral health care providers). J Pak Med Assoc 2011;10:1009-14.

17. Ferraro $M$, Vieira AR. Explaining gender differences in caries: a multifactorial approach to a multifactorial disease. Int $J$ Dent 2010;2010:649643.

18. Vogt M, Sallum AW, Cecatti JG, Morais SS. Factors associated with the prevalence of periodontal disease in low-risk pregnant women. Reprod Health 2012;9:3.

19. Usin MM, Tabares SM, Parodi RJ, Sembaj A. Periodontal conditions during the pregnancy associated with periodontal pathogens. J Investig Clin Dent 2013;1:54-9.

20. Marla V, Kathmandu University K, Nepal, Kathmandu University K, Nepal, Srii R, Kathmandu University K, Nepal, Kathmandu University K, Nepal, et al. The Importance of Oral Health during Pregnancy: A review. MedicalExpress 2018;5.

21. Acharya S, Bhat PV. Factors affecting oral health-related quality of life among pregnant women. Int J Dent Hyg 2009;2:102-7.

22. Boggess KA, Edelstein BL. Oral health in women during preconception and pregnancy: implications for birth outcomes and infant oral health. Matern Child Health J 2006;5 Suppl:S169-74.
23. Cetin I, Pileri P, Villa A, Calabrese S, Ottolenghi L, Abati S. Pathogenic mechanisms linking periodontal diseases with adverse pregnancy outcomes. Reprod Sci 2012;6:633-41.

24. Preshaw PM, Bissett SM. Periodontitis: oral complication of diabetes. Endocrinol Metab Clin North Am 2013;4:849-67.

25. Preshaw PM, Alba AL, Herrera D, Jepsen S, Konstantinidis A, Makrilakis $\mathrm{K}$, et al. Periodontitis and diabetes: a two-way relationship. Diabetologia 2012;1:21-31.

26. Silk H, Douglass AB, Douglass JM, Silk L. Oral health during pregnancy. Am Fam Physician 2008;8:1139-44.

27. Robinson PJ, Schmerman M. Influence of Pregnancy on the Oral Cavity. The Global Library of Women's Medicine. 2015.

28. Srivastava AK, Gupta KK, Srivastava S, Garg J. Effects of sex hormones on the gingiva in pregnancy: a review and report of two cases. $J$ Periodontol Implant Dent 2011;2: 83-87.

29. Madianos PN, Bobetsis YA, Offenbacher $S$. Adverse pregnancy outcomes (APOs) and periodontal disease: pathogenic mechanisms. $\mathrm{J}$ Clin Periodontol 2013;Suppl14:S170-80.

30. Socransky SS, Haffajee AD, Cugini MA, Smith $\mathrm{C}$, Kent RL. Microbial complexes in subgingival plaque. J Clin Periodontol 1998;2:134-44.

31. Jain K, Kaur H. Prevalence of oral lesions and measurement of salivary $\mathrm{pH}$ in the different trimesters of pregnancy. Singapore Med J 2015;1:53-7.

32. Featherstone JD. Dental caries: a dynamic disease process. Aust Dent J 2008;3:286-91.

33. Cotti E, Dessì C, Piras A, Mercuro G. Can a chronic dental infection be considered a cause of cardiovascular disease? A review of the literature. Int J Cardiol 2011;1:4-10.

34. Segura-Egea JJ, Martín-González J, Cabanillas-Balsera D, Fouad AF, VelascoOrtega E, López-López J. Association between diabetes and the prevalence of radiolucent periapical lesions in root-filled teeth: systematic review and meta-analysis. Clin Oral Investig 2016;6:1133-41.

35. Segura-Egea JJ, Castellanos-Cosano L, Machuca G, López-López J, Martín-González J, Velasco-Ortega $E$, et al. Diabetes mellitus, periapical inflammation and endodontic treatment outcome. Med Oral Patol Oral Cir Bucal 2012;2:e356-61.

36. Sasaki $H$, Hirai $K$, Martins CM, Furusho $H$, Battaglino R, Hashimoto K. Interrelationship Between Periapical Lesion and Systemic Metabolic Disorders. Curr Pharm Des 2016;15:2204-15.

37. Segura-Egea JJ, Martín-González J, Castellanos-Cosano L. Endodontic medicine: connections between apical periodontitis and systemic diseases. Int Endod J.2015;10:933-51. 
38. Carta G, Persia G, Falciglia K, lovenitti P. Periodontal disease and poor obstetrical outcome. Clin Exp Obstet Gynecol 2004;1:47-9.

39. Pålsson-McDermott EM, O'Neill LA. Signal transduction by the lipopolysaccharide receptor, Toll-like receptor-4. Immunology 2004;2:15362.

40.Lu Y, Yeh W, Ohashi PS. LPS/TLR4 signal transduction pathway. Cytokine 2008;45:14551.

41. Medzhitov R. Toll-like receptors and innate immunity. Nat Rev Immunol 2001;2:135-45.

42. Takeuchi O, Sato S, Horiuchi T, Hoshino K, Takeda K, Dong Z, et al. Cutting edge: role of Toll-like receptor 1 in mediating immune response to microbial lipoproteins. J Immunol 2002;1:10-4.

43.Zi MY, Longo PL, Bueno-Silva B, Mayer MP. Mechanisms Involved in the Association between Periodontitis and Complications in Pregnancy. Front Public Health 2015;2:290.

44. Gandhimadhi D, Mythili R. Periodontal infection as a risk factor for preterm low birth weight. J Indian Soc Periodontol 2010;2:114-20.

45. Cappelli D, Steffen MJ, Holt SC, Ebersole JL. Periodontitis in pregnancy: clinical and serum antibody observations from a baboon model of ligature-induced disease. $\mathrm{J}$ Periodontol 2009;7:1154-65.

46. Blanc V, O'Valle F, Pozo E, Puertas A, León R, Mesa F. Oral bacteria in placental tissues: increased molecular detection in pregnant periodontitis patients. Oral Dis 2015;7:905-12.

47. Walia M, Saini N. Relationship between periodontal diseases and preterm birth: Recent epidemiological and biological data. Int J Appl Basic Med Res 2015;1:2-6.

48. Katz J, Chegini N, Shiverick KT, Lamont RJ. Localization of $\mathrm{P}$. gingivalis in preterm delivery placenta. J Dent Res 2009;6:575-578.

49. Michelin MC, Teixeira SR, Ando-Suguimoto ES, Lucas SR, Mayer MP. Porphyromonas gingivalis infection at different gestation periods on fetus development and cytokines profile. Oral Dis 2012;7:648-54.

50. Ao M, Miyauchi M, Furusho $\mathrm{H}$, Inubushi $\mathrm{T}$, Kitagawa M, Nagasaki $A$, et al. Dental infection of Porphyromonas gingivalis induces preterm birth in mice. PLoS One 2015;8:e0137249.

51. Ivanisević M, Djelmis J, Buković D. Review on prostaglandin and oxytocin activity in preterm labor. Coll Antropol 2001;2:687-694.

52. Mueller A, Maltaris $T$, Siemer J, Binder $H$, Hoffmann I, Beckmann MW, et al. Uterine contractility in response to different prostaglandins: results from extracorporeally perfused non-pregnant swine uteri. Hum Reprod 2006;8:2000-5.
53. Offenbacher S, Beck JD, Lieff S, Slade G. Role of periodontitis in systemic health: spontaneous preterm birth. J Dent Educ 1998;10:852-8.

54. Inglis SR. Biochemical markers predictive of preterm delivery. Infect Dis Obstet Gynecol 1997;2:158-64.

55.Perunovic NDj, Rakic MM, Nikolic LI, Jankovic $\mathrm{SM}$, Aleksic ZM, Plecas DV, et al. The association between periodontal inflammation and labor triggers (elevated cytokine levels) in preterm birth: a cross-sectional study. J Periodontol 2016;3:248-56.

56. Collins JG, Windley HW, Arnold RR, Offenbacher S. Effects of a Porphyromonas gingivalis infection on inflammatory mediator response and pregnancy outcome in hamsters. Infect Immun 1994;10:4356-61.

57. Yeo A, Smith MA, Lin D, Riché EL, Moore A, Elter J, et al. Campylobacter rectus mediates growth restriction in pregnant mice. $\mathrm{J}$ Periodontol 2005;4:551-7.

58. Lin D, Smith MA, Champagne C, Elter J, Beck $\mathrm{J}$, Offenbacher S. Porphyromonas gingivalis infection during pregnancy increases maternal tumor necrosis factor alpha, suppresses maternal interleukin-10, and enhances fetal growth restriction and resorption in mice. Infect Immun 2003;9:5156-62.

59. Bobetsis YA, Barros SP, Lin DM, Arce RM, Offenbacher $\mathrm{S}$. Altered gene expression in murine placentas in an infection-induced intrauterine growth restriction model: a microarray analysis. J Reprod Immunol 2010;2:140-8.

60. Offenbacher S, Katz V, Fertik G, Collins J, Boyd $D$, Maynor G, et al. Periodontal infection as a possible risk factor for preterm low birth weight. J Periodontol 1996;10Suppl:1103-13.

61. Kumar H, Mishra M, Bajpai S, Pokhria D, Arya AK, Singh RK, et al. Correlation of insulin resistance, beta cell function and insulin sensitivity with serum sFas and sFasL in newly diagnosed type 2 diabetes. Acta Diabetol 2013;4:511-8.

62.López NJ, Da Silva I, Ipinza J, Gutiérrez J. Periodontal therapy reduces the rate of preterm low birth weight in women with pregnancyassociated gingivitis. J Periodontol 2005;11 Suppl:2144-53.

63. Saddki N, Bachok N, Hussain NH, Zainudin SL, Sosroseno W. The association between maternal periodontitis and low birth weight infants among Malay women. Community Dent Oral Epidemiol 2008;4:296-304.

64. Wang J, Cao M, Yang M, Lin Y, Che L, Fang Z, et al. Intra-uterine undernutrition amplifies ageassociated glucose intolerance in pigs via altered DNA methylation at muscle GLUT4 promoter. Br J Nutr 2016;3:390-401. 
65. Mattera MSLC, Chiba FY, Lopes FL, Tsosura TVS, Peres MA, Brito VGB, et al. Effect of maternal periodontitis on GLUT4 and inflammatory pathway in adult offspring. $J$ Periodontol 2019;90(8):889-93.

66. Mattera MS, Chiba FY, Mota MS, Pereira RF, Ervolino E, Chaves Neto AH, et al. Maternal periodontitis decreases plasma membrane GLUT4 content in skeletal muscle of adult offspring. Life Sci 2016;148:194-200.

67. López NJ, Smith PC, Gutierrez J. Higher risk of preterm birth and low birth weight in women with periodontal disease. J Dent Res 2002;1:58-63.

68. Offenbacher S, Riché EL, Barros SP, Bobetsis YA, Lin D, Beck JD. Effects of maternal Campylobacter rectus infection on murine placenta, fetal and neonatal survival, and brain development. $\mathrm{J}$ Periodontol 2005;11Suppl:2133-43.

69. Horáková D, Janoutová G, Janout V. Insulin resistance and birth weight. Biomed Pap Med Fac Univ Palacky Olomouc Czech Repub 2005;1:173-6.

70. Tsosura TVS, Chiba FY, Mattera MSLC, Pereira RF, Cintra LTA, Conti LC, et al. Maternal apical periodontitis is associated with insulin resistance in adult offspring. Int Endod J 2019;7:1040-50.

\section{CONFLICTS OF INTERESTS}

The authors declare no conflicts of interests.

\section{CORRESPONDING AUTHOR}

\section{Maria Sara de Lima Coutinho Mattera}

São Paulo State University (Unesp),

School of Dentistry, Araçatuba, Brazil

R. José Bonifácio, 1193,

16015-050 Araçatuba-SP, Brazil.

Email:mariasara_Ic@hotmail.com

Received 02/02/2021

Accepted 15/10/2021 